\title{
A Decorated Jar of the Byzantine Period in the Museo Egizio, Turin (Suppl. 15626)
}

\author{
Ilaria Incordino \\ With a contribution by Federica Facchetti
}

The article analyses a previously unpublished painted jar from the Byzantine Period discovered by Ernesto Schiaparelli at Asyut, possibly in 1911, and presently kept at the Museo Egizio, Turin (S. 15626). The distinctive female figure represented on the upper half of the body of the vessel is rather rare in the Byzantine repertoire. The author compares it with similar figures found on different supports and in different contexts. Notably, she highlights parallels with painted pottery from the monastery of Abba Nefer the Hermit at Manqabad, as well as in pottery assemblages from Kellia, Saqqara, Esna, Tebtynis, Deir el Bachit (West Thebes), and especially towns in Middle Egypt such as Amarna (Kom el-Nana), El-Ashmunein, Antinoopolis and Wadi Sarga. The probably non-religious female figure may be an instance of the well-known tendency in Byzantine Egypt to draw on the Hellenistic repertoire, especially in depictions of figures of prosperity and good luck, which would have been easily recognizable by both Christians and pagans.

ملخص البحث:

تحلل المقالة إناء ملون لم يتم نشره من قبل يعود إلى العصر البيزنطي، اكتثفه "إرنستو شياباريلي" في أسيوط، في عام 1911 على الأرجح، وهو محفوظ حاليًا في المتحف المصري بتورينو (S. 15626). الثكل الأنثوي المميز المعروض في النصف العلوي من جسم الإناء شديد الندرة في مجموعة أعمال العصر البيزنطي. يقارن المؤلف الثكل الموجود على الجزء العلوي من الإناء بالأشكال المتشابهة الموجودة في مناسبات وسياقات مختلفة. تجدر الإشارة إلى أن الثكل يُبرز أوجه التشابه مع الفخار الملون بدير أبو نفر السائح في منقباد، وكذلك في مجموعات الفخار الموجودة في منطقة كيليا وسقارة وإسنا وتبتنيس ودير البشت (غرب طيبة)، وبشكل خاص مدن مصر الوسطى مثل العمارنة (كوم النعناع) والأشمونين وانطيونوبوليس ووادي سرجة. ربما يكون شكل الشخصية الأنثوية غير الديني مثالًا على النزعة المعروفة في مصر البيزنطية من خلال الارتكاز على مجموعة أعمال العصر الهلنستي، لا سيما في تصوير أشكال الرخاء والحظ السعيد، والتي كان يمكن التعرف عليها بسهولة لكل من المسيحيين والوثنيين.

\section{Introduction}

This paper presents an analysis of the painted decoration of a large jar from the Byzantine period with a distinctive painted human figure held in the $\mathrm{Mu}-$ seo Egizio in Turin (Suppl. 15626, Figs. 1-3) and deriving from Schiaparelli's excavation at Asyut in 1911. Since anthropomorphic (and possibly female) representations are quite rare on Byzantine pottery in general, the presence of a similar decoration on a fragmentary cup on a high foot deriving from the ar- chaeological mission at Manqabad, Asyut, ${ }^{1}$ appeared of interest (inv. no. Minya 1570; Manq. 61, Fig. 4). Unfortunately, both items suffer from a lack of relevant archaeological context. The Turin jar appears in the list of "dispersed" (=out-of-context) finds relative to the Italian mission's campaigns of 1911, 1912, and 1913. Interestingly, in all three of these years the diggers mainly worked on the slopes downhill from the ruins of the monastery of Deir el-Azzam (probably fifth century AD) and from a Coptic chapel, with 
the 1912 excavation actually extending to the latter. ${ }^{2}$ Therefore, to propose a date for Turin Suppl. 15626, some parallels with stratified pottery (or, more generally, pottery dated by stylistic and iconographic criteria) bearing similar decoration will be presented in the following pages, possibly to be traced to the same workshop in Middle Egypt.

\section{Description of the Turin jar 2.1 Shape, fabric and colours}

\section{(Federica Facchetti)}

The wheel-turned jar (Fig. 1) is $48.4 \mathrm{~cm}$ high, the maximum diameter is $33.4 \mathrm{~cm}$, the diameter of the mouth is $18.2 \mathrm{~cm}$, and that of the foot is $13 \mathrm{~cm}$. The fabric is a Nile silt with an abundance of straw of different sizes, sand, and limestone inclusions. The jar has a straight rim with a rectangular section, a distinct neck with concave sides graced with six applied cordons, and two small lugs at the base of the neck. The body is ellipsoid in its upper part and coneshaped under the carination, and has a ring foot. In the lower part of the body, below the carination, there are three rows of rope impressions. Also below the carination are three traces of firing defects.

The jar is covered with a red slip from rim to foot, and with a painted decoration from the rim to the carination. This decoration is in three colours: black, white and red, applied sequentially. The painter first drew the black lines bordering the registers, then those on the lugs and the neck (one continuous and

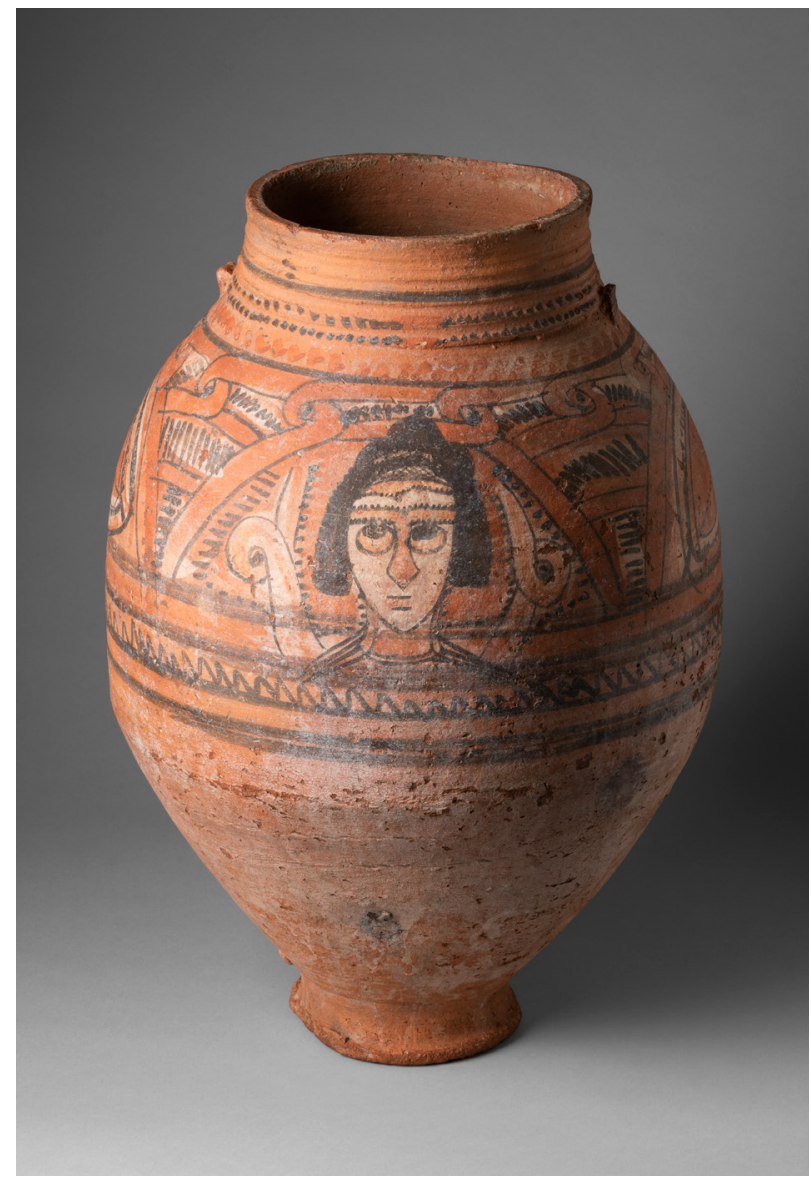

Fig. 1: Turin Suppl. 15626. Photo by Nicola Dell'Aquila and Federico Taverni/Museo Egizio.

two dotted). Then the painter applied the red and after that the white, except for the bust, where the white was spread before the red. The last colour to be applied was the black, and the last lines to be drawn were the two under the bust.
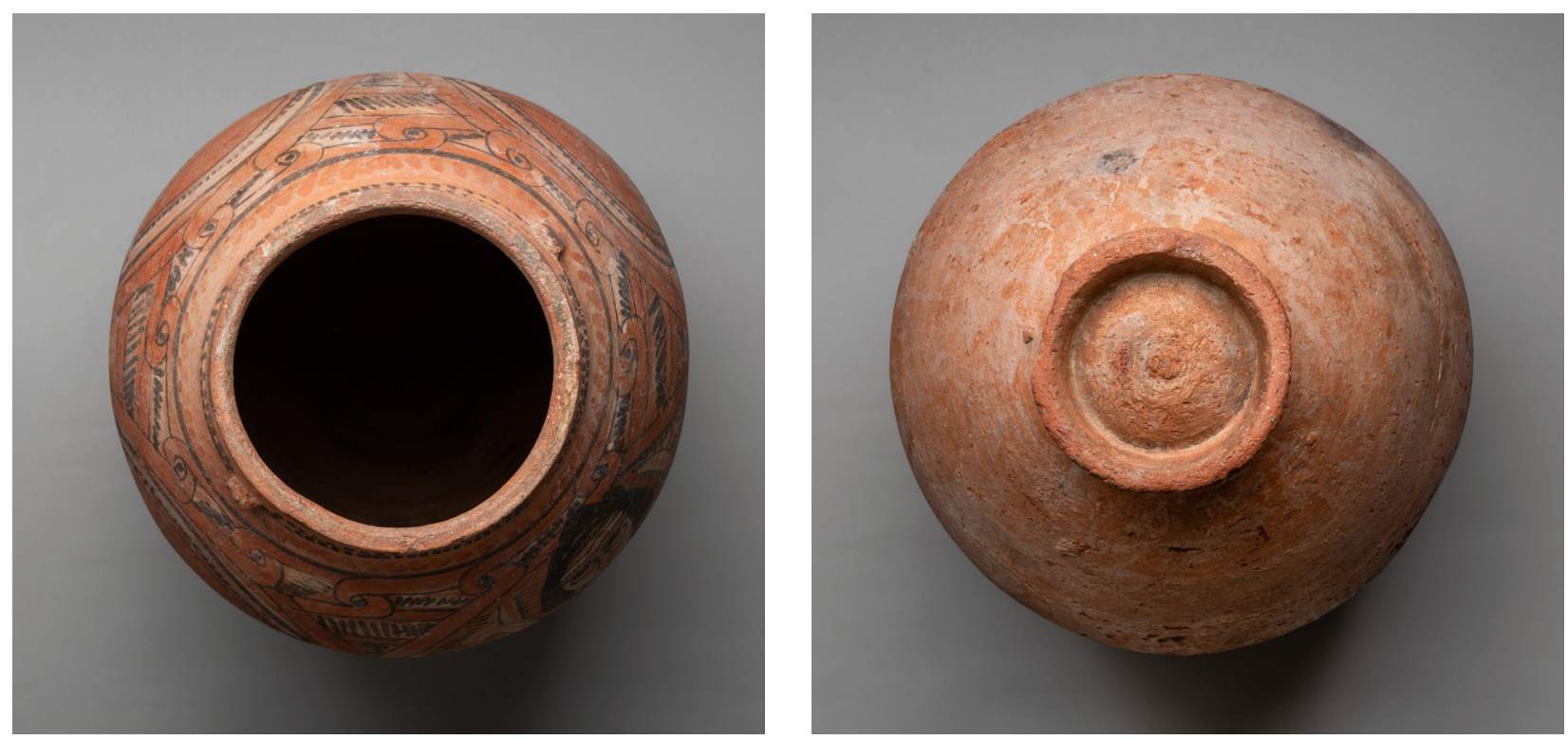

Fig. 2: Turin Suppl. 15626 (mouth and foot). Photos by Nicola Dell'Aquila and Federico Taverni/Museo Egizio. 

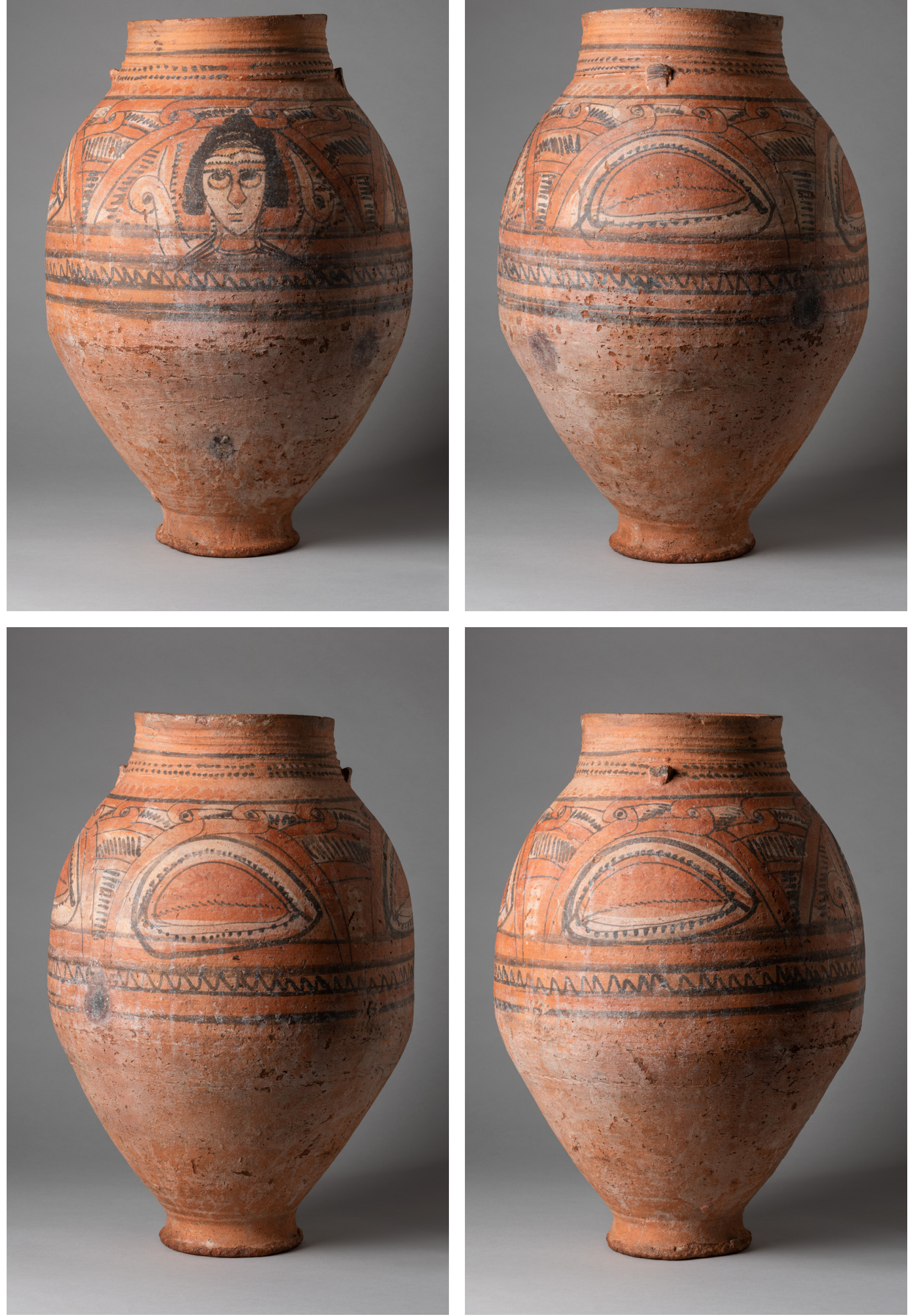

Fig. 3: Turin Suppl. 15626. Photos by Museo Egizio/Nicola Dell'Aquila and Federico Taverni. 

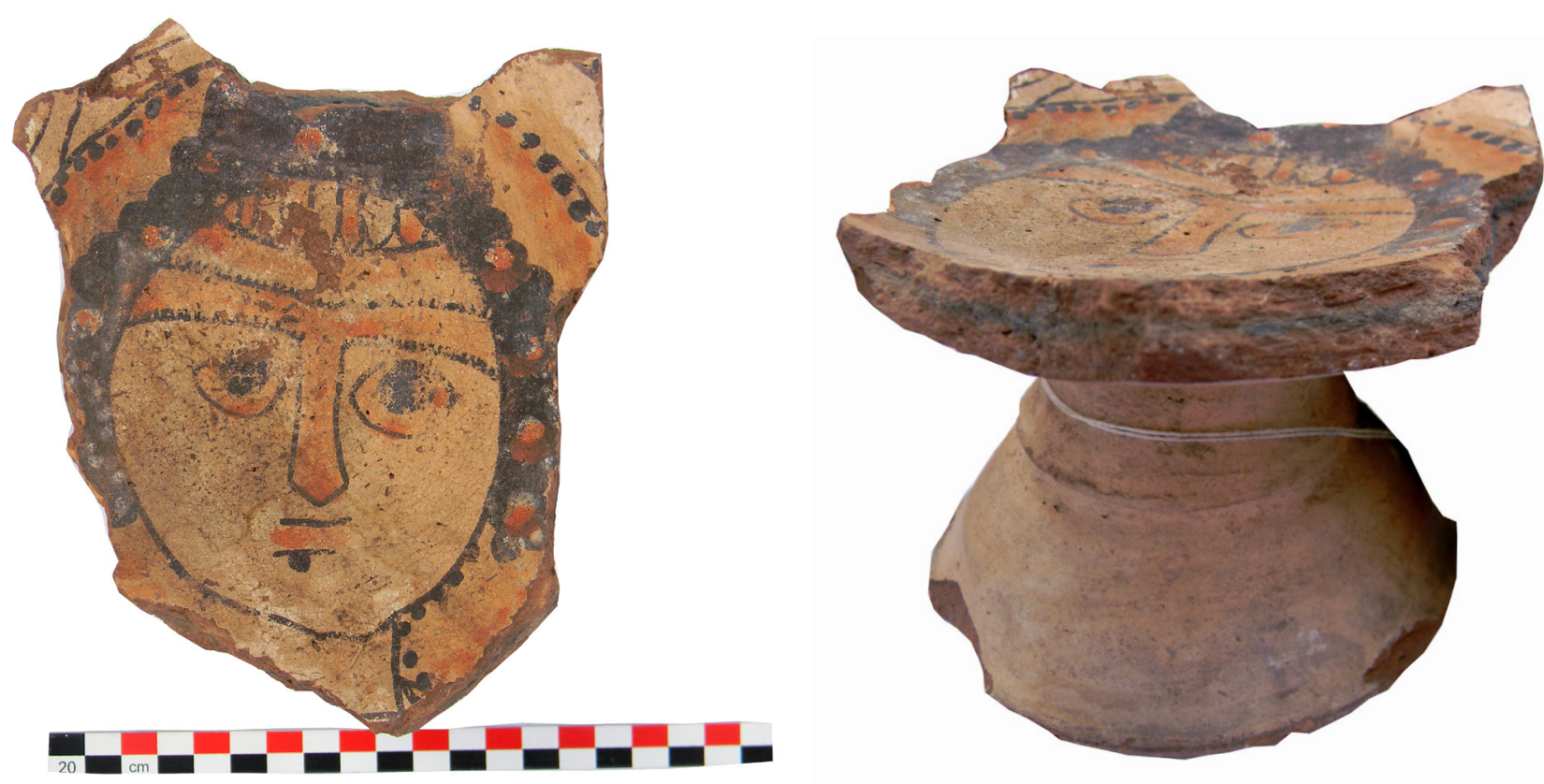

Fig. 4: Manqabad raised cup with painted decoration (Inv. Minya 1570, Manq. 61). Photo by the author.

\subsection{Decoration}

As usual for this type, the painted decoration covers only the upper half of the outer surface. It includes four figurative "panels" between horizontal borders, framed by four intertwining arches with stylised foliage. Three "panels" show a leaf, a common motif on this type of storage jar, which was used for storing water or foodstuffs in monastic communities.

Similar decoration can be seen on the back of a tall jar from the monastery of Apa Jeremiah at Saqqara, presently in the Coptic Museum in Cairo (inv. no. 9065) and dated to the sixth century AD. ${ }^{3}$

In the fourth panel there is a "bust" of a human figure, with an elaborate coiffure, big rounded eyes and a large nose whose outline is continuous with that of the eyebrows. The mouth is lightly sketched in red with black outlines. The figure wears a tunic. Some details are rendered quite accurately, namely, the black dots surrounding the head and neck; the hairs of the eyebrows, sketched in black; and a sort of diadem on the forehead, which shows a mesh pattern rendered with black lines on a white background. The figure, which appears to be female, is enclosed in a semicircle bounded by creamy reddish arches outlined in black on a red ground.

\section{Description of the Manqabad cup}

A painted head very similar to that depicted on the
Turin jar graces a cup on a high foot from the site of Manqabad (Inv. Minya 1570, Manq. 61, Fig. 4). This fragmentary item derives from the 2002/2003 excavation undertaken by the SCA Inspectors, which focused on the central part of the northern housing-unit row. Since 2014, this sector of the site (designated as the "Northern Sector") has been the object of an archaeological and topographical survey by the Università degli Studi di Napoli “l'Orientale”. The survey has led to the identification of a small church or oratory at the western end of the monastic housing units, corresponding to HU8 (Housing Unit 8). From this area derives $78 \%$ of the (decorated) pottery documented so far, which was probably part of the ritual equipment used by the local monastic community. The Nile clay vessel is composed of a high foot $(8 \mathrm{~cm}$ high) and what is left of the central part of a painted cup, with a pale cream slip. The fabric is reddish with a black thin core and many white inclusions. The maximum preserved diameter is $14 \mathrm{~cm}$ and the total height $10.5 \mathrm{~cm}$. On the inside is painted the head of a woman with elaborately coiffed curly hair adorned with red beads (pearls?) and a vertical red and cream band on her forehead (a row of pearls?). Her eyes are large and round, outlined in black, while the mouth is sketched lightly in red with a black dot underneath, giving the effect of shading between mouth and chin. The eyebrows are rendered as a contin- 

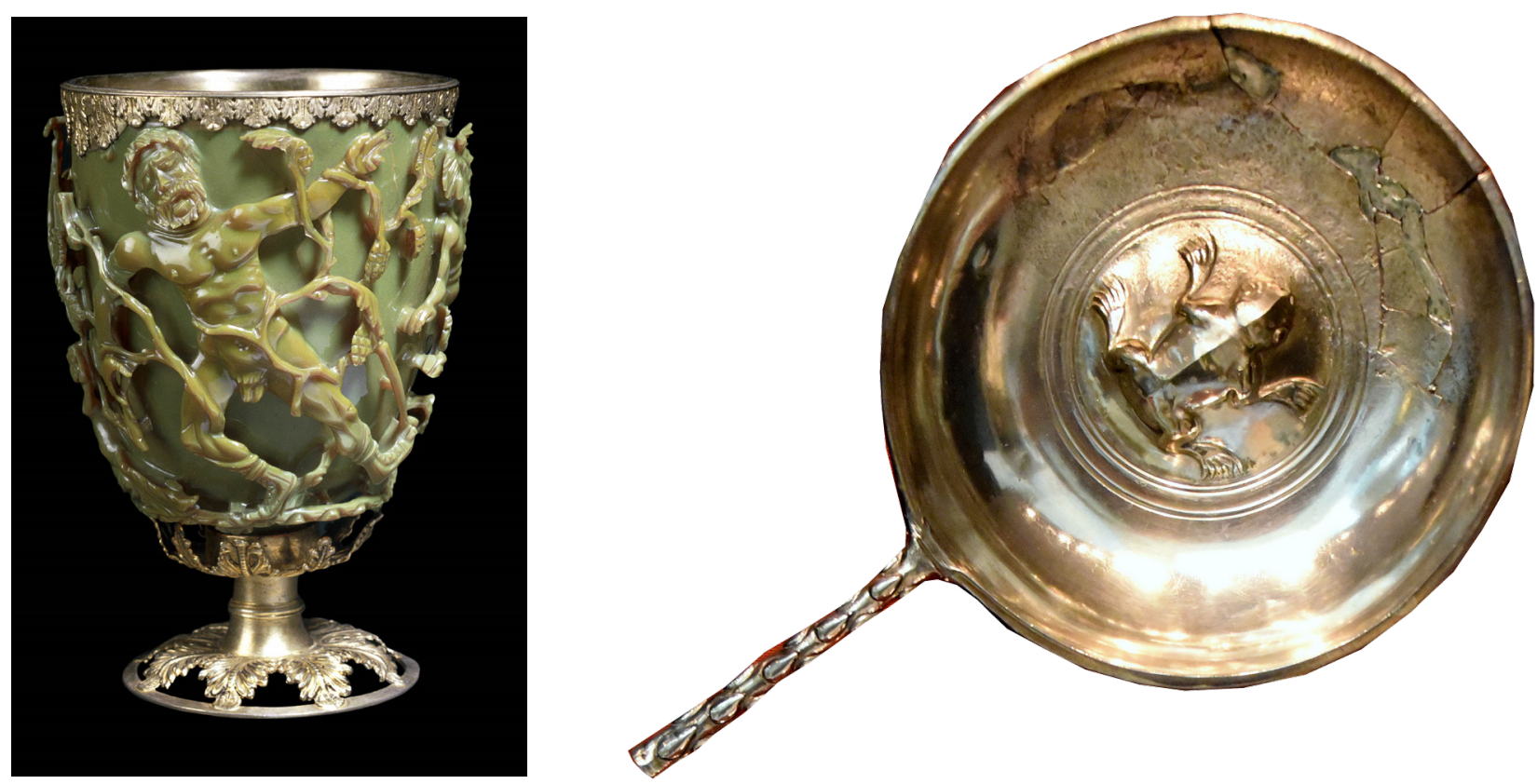

Fig. 5: Left: Lycurgus cup, BM 1958,1202.1. Right: patera with frog from the Carthage treasure BM AF3279, mid-fourth century AD.

uous red line, with their hairs indicated by rows of small black dots, meeting the nose line at a right angle. The figure is possibly included in a round (?) frame formed of black dots on a red background, still clearly visible on either side of the head. This female figure is an exceptional occurrence in the habitual decorative repertoire of painted geometrical and vegetal themes found on the pottery of Manqabad.

The greatest difficulties one encounters in dealing with the site assemblage arise from the absence of a secure archaeological context for the finds (this is also true of other materials than ceramics), due to a complete lack of documentation for the previous archaeological surveys, conducted by SCA inspectors. Moreover, the previous excavators collected mainly complete vessels with painted decoration (only 12\% of the material analysed so far is coarse ware). Demonstrative of this method of work is the fact that in the el-Ashmunein SCA stores there are currently no sherds from the site. For this reason, it has so far been impossible to carry out a study of fresh breaks. Consequently, the date suggested for the cup here is mainly based on stylistic and morphological parallels found at other sites in secure archaeological contexts, such as a cup on a high foot in the Louvre Museum (E11756; possibly from Saqqara, St. Jeremiah; base height $6.8 \mathrm{~cm}$, inner diameter $24 \mathrm{~cm}$.) dated to the sixth-seventh century AD.

\section{Function and decoration}

There is often a strong association between the function of pottery vessels and the images decorating them. In Late Antique Roman times (since the third century $\mathrm{AD}$ ), for example, we have a clear understanding of the relationship between geometrical decorative themes and mosaic floor patterns, or vessel decoration and the domestic context in which the vessel would have been typically used (according to Vitruvius: cum aedificis interioribus magnificis item vestibula convenientia et elegantia erunt facta "when harmonious and elegant vestibules are also made for magnificent interiors", De Architectura 1.2.6), where the decorative themes on pottery or metal items reproduced the inner decoration of a room. ${ }^{4}$ Such a connection is also evident in the presence of the goddess Venus (or aquatic themes in general, Fig. 5) on paterae used as water containers for washing, or scenes depicting the Last Supper shown on Eucharist chalices, or the Bacchic scenes on the Lycurgus cup. The connection between decoration and the actual function of the object seems even stronger in religious contexts, ${ }^{5}$ where the decoration plays an active role in transforming the object into a ritual item in order to increase the effectiveness of the ceremonial act. In this respect, cups or beakers associated with water or wine are often decorated with aquatic or Bacchic themes, ${ }^{6}$ in a mixed pagan and Christian 


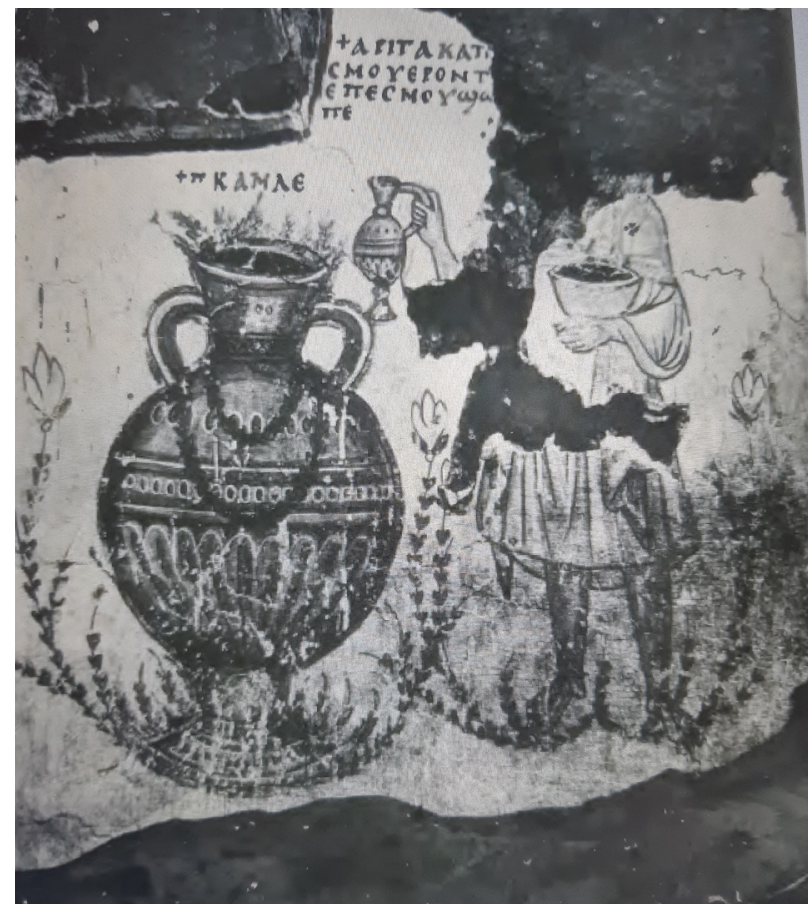

Fig. 6: Figure with wine amphora. Bawit monastery, Cell 17. From Cledat, Le Monastère, 1904, pl. 55.

funerary and redemptive symbolism.

An interpretation could thus be tentatively proposed for the Manqabad cup as a ritual wine container, because of the Dionysiac "portrait" gracing its inner surface. As regards the Turin jar, some pictorial evidence from the monastery of Bawit could support a similar interpretation as a wine container (Fig. 6), even though there are important morphological differences between the amphora in the Bawit fresco and the Turin jar. The latter only has two small decorative lugs at the base of the neck, a ring foot and a peculiar anthropomorphic decoration on the upper part of the outer surface. Despite this, the Bawit painting is quite interesting, since it represents rituals performed with pottery items. In this depiction, the deacon prepares himself to receive the Eucharist. The wine contained in the amphora will be transformed into Christ's blood and then consumed by the monks as part of the process of assimilating Christ. ${ }^{7}$ Three vessels are directly involved in this ceremony, including what seems to be a large cup held in the deacon's left hand. Unfortunately, the decoration of the vessels is not clear enough to enable an accurate parallel with the items described above, except for the amphora, which however bears only vegetal and geometric motifs.

\section{Female representations on Byzantine pottery}

The anthropomorphic theme is in general rather neglected in the Christian Egyptian pottery repertoire of decoration, and as a rule very schematic when present. In many instances, no clear indicator is provided of the gender of the represented figure, which is generally referred in the literature to as a "hu-
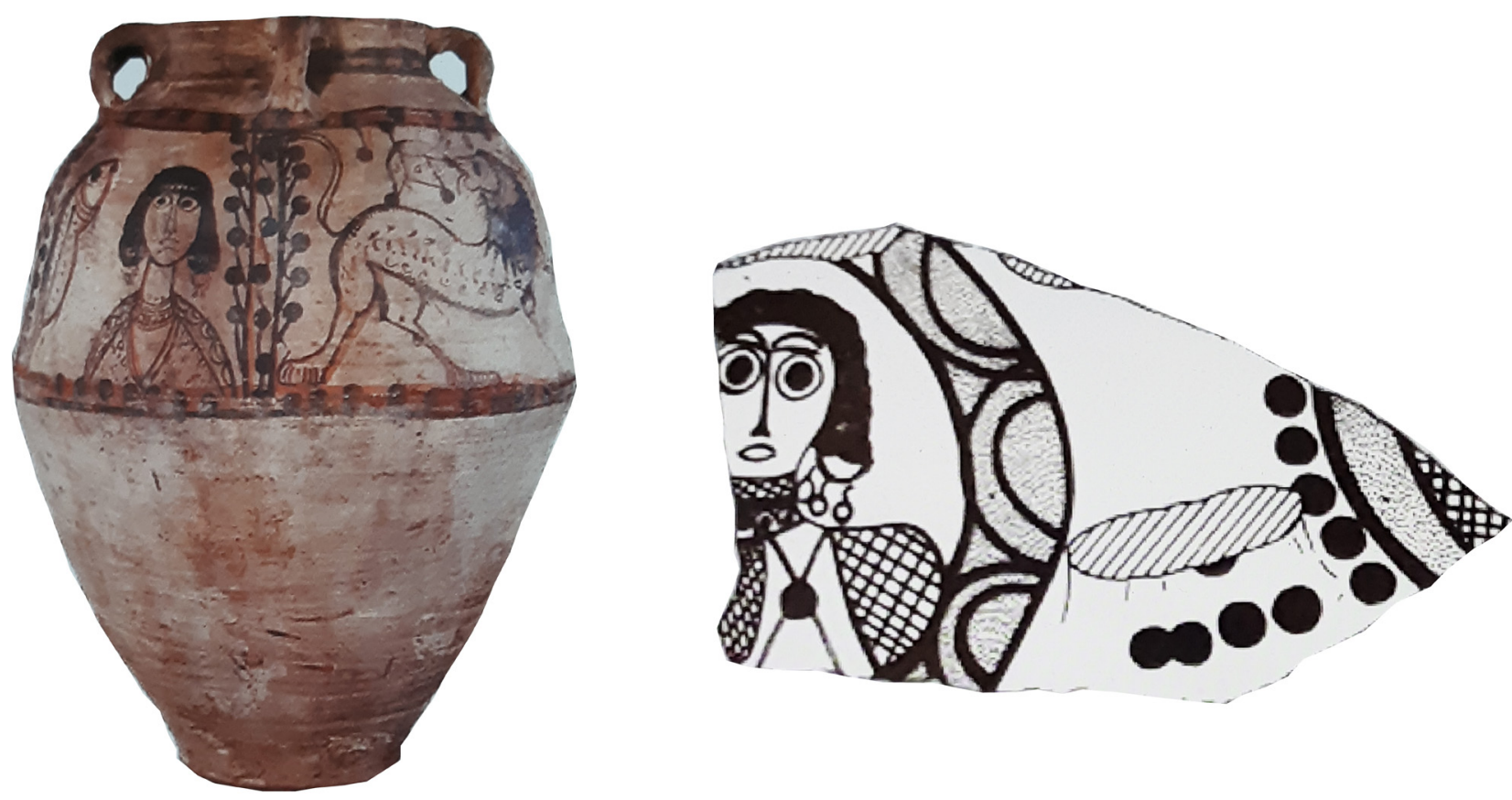

Fig. 7: Example of a female headdress with hair rings on a biconical jar, Louvre E 10993, h. $50 \mathrm{~cm}$; photo by the author. The same on a jar sherd from Tell Atrib; drawing by Górecki, in Godlewski (ed.), Coptic and Nubian Pottery, p. 45. 


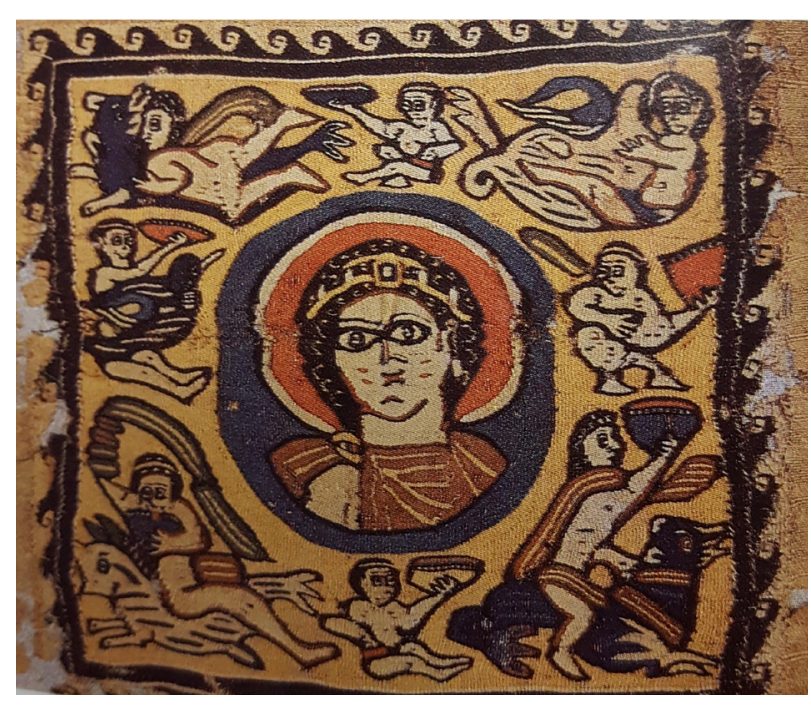

Fig. 8: Textile from Antinoe (Coptic Museum, Cairo, inv. no. 8473). Photo public domain.

man figure" or "bust". Recognizable female images are, therefore, even more rare and usually roughly sketched, ${ }^{8}$ except for a few instances, such as a body sherd from Saqqara, held in the Fitzwilliam Museum in Cambridge ${ }^{9}$ (E.19.1971), with a remarkable rendering of a bejewelled woman, dated to the fifth-tomid-sixth century AD.

The interpretation of these female figures has long been debated: could they be portraits of an empress or a pagan goddess? A religious subject? Or a composite of the above ${ }^{10}$ It is actually quite likely that these woman figures derive from Roman prototypes of personifications of the Earth, Good Fortune, Prosperity, or from the so-called "Dionysiac portrait". The latter is also a very frequent theme on Byzantine textiles, mosaics and wall paintings, where it is still employed for its auspicious and protective power. ${ }^{11}$ An example of this influence is the decoration of the headdress with rings, possibly deriving from a Byzantine diadem. This feature can be found, for instance, on a jar fragment from Tell Atrib dated to the late sixth or early seventh century AD (Fig. 7b), and on a painted ovoid jar, presently at the Louvre Museum, dated to the sixth-eighth century AD (E 10993, Fig. 7a).

Moreover, the tondo figures on pottery are remindful of some textile tabulae depicting bejewelled and richly dressed women - usually identified as divinities - as images associated with prosperity and abundance (e.g. Fig. 6, sixth-seventh century AD). According to some scholars, female busts are "sys- tematically associated with representations of male and/or female musicians, seated or standing under arcades". ${ }^{12}$ Some Late Roman papyri state that musicians were employed to perform during religious festivals, and the representation of Nilotic motifs with male and female dancers or musicians could also be cited as evidence in support of this hypothesis. ${ }^{13}$ Even if some feminine images on Byzantine pottery are actually not associated with music or Nilotic scenes, the hypothesis that these images are depictions of the performance of religious rituals is interesting and worthy of a closer examination.

\section{Stylistic and iconographic analysis}

The Turin jar derives from Schiaparelli's archaeological expedition to Asyut, and probably more specifically from the 1911 season (based on the inventory number). It arrived in Turin in 1913. The excavation notebook by Virginio Rosa mentions the beginning of the 1911 season of Italian field work at Asyut in the north-east sector of the Muslim necropolis, part of the archaeological concession. At a depth of about $3 \mathrm{~m}$, the remains of possibly Byzantine buildings of

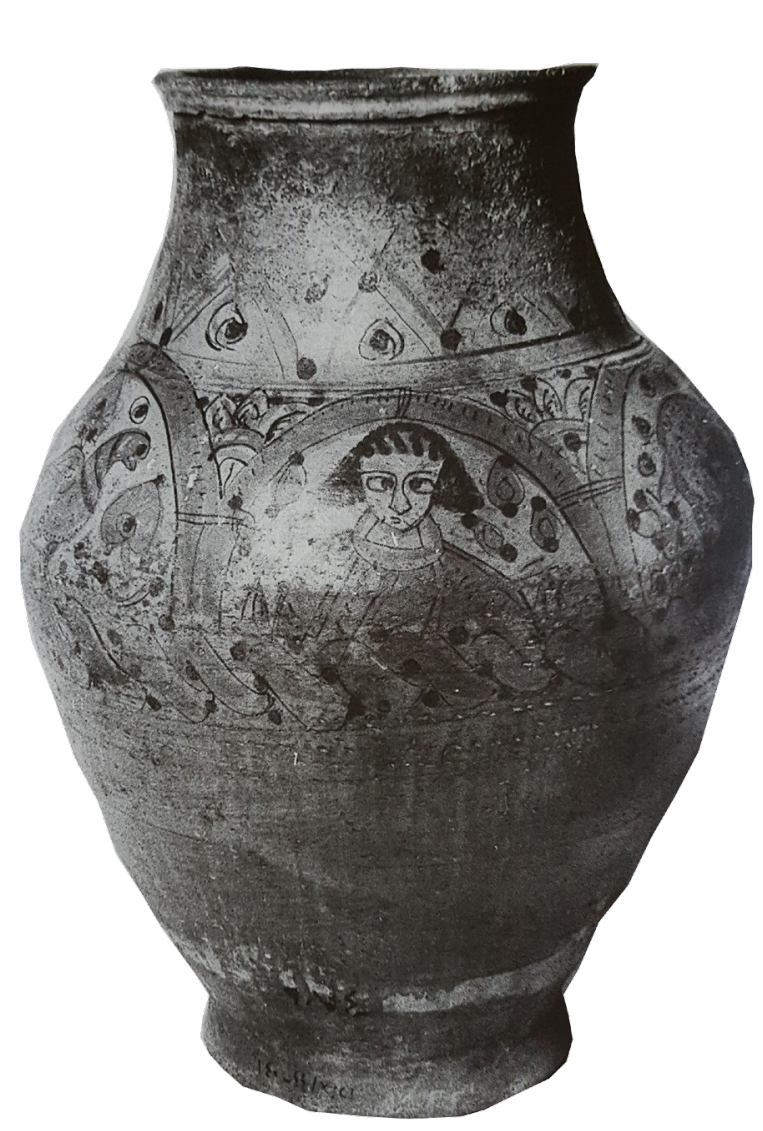

Fig. 9: Type C "Saqqara jar", Coptic Museum of Cairo, inv. no. 9074. From Mohamed, in: Immerzeel and van der Vliet (eds.), Coptic Studies, p. 1252. 
mudbrick were found. In other passages of the report, Rosa mentions some "Coptic crypts", without providing additional information. Unfortunately, no pottery finds are mentioned in the text in connection with any Coptic-related buildings. ${ }^{14}$ Consequently, no useful information about archaeological context is available for the Byzantine pottery from Asyut in the Turin museum. This material hence cannot be used to further corroborate the date hypothesized by the present writer for the Manqabad material. ${ }^{15}$ Despite this, there are stylistic and iconographic parallels for the Turin jar that can help to suggest a possible date.

The general layout of the decoration of the Turin jar bears very close similarities to an ovoid jar of unknown provenance in the Coptic Museum in Cairo (inv. no. 9074, Fig. 9). The latter has a quadripartite register divided by overlapping arches. In one of these arches there is a representation of a human bust clad in a tunic.

The distinctive characteristics shared by the two images are: the rendering of the nose, with its angular tip, the triangular shape of the face, and the position of the figure inside overlapping arches. The Turin "bust", however, has a more elaborate set of accessories (mainly jewels), while the Cairo figure has a plainer appearance. The dimensions, too, are very close: the height of the Cairo jar is $59.4 \mathrm{~cm}$, with a maximum diameter of $43 \mathrm{~cm}$ and a rim diameter of $25.5 \mathrm{~cm}$.

A provenance from the atelier in Apa Jeremiah at Saqqara has been hypothesized for the Cairo jar, based mainly on the stylistic elements of the decoration and similarities with the so-called "Saqqara Jars", group C (ovoid jars with the decoration on the upper half of the vessel divided into registers by overlapping arches). A date between the sixth and seventh century AD has been therefore suggested. ${ }^{16}$ An additional comparison could be made with a pottery sherd from Wadi Sarga (British Museum E73599; height $18.3 \mathrm{~cm}$, currently in press) with a depiction of a possibly male character. Here it is possible to notice further similarities with the Cairo jar, most notably the headdress with $4-5$ rows of hair hanging over the forehead. The Wadi Sarga fragment has been dated to the sixth century AD. ${ }^{17}$

While the Cairo jar and the Wadi Sarga sherd could possibly depict a male figure, a comparison between the figures on the Turin jar and the Manqabad cup instead supports the hypothesis that both are female. The two figures have many distinctive female features in common: the headdress, for example, is in both instances very elaborate, with a central chignon and two lateral bands of hanging hair (Fig. 10). On both vases, the figures have pearls in their hair

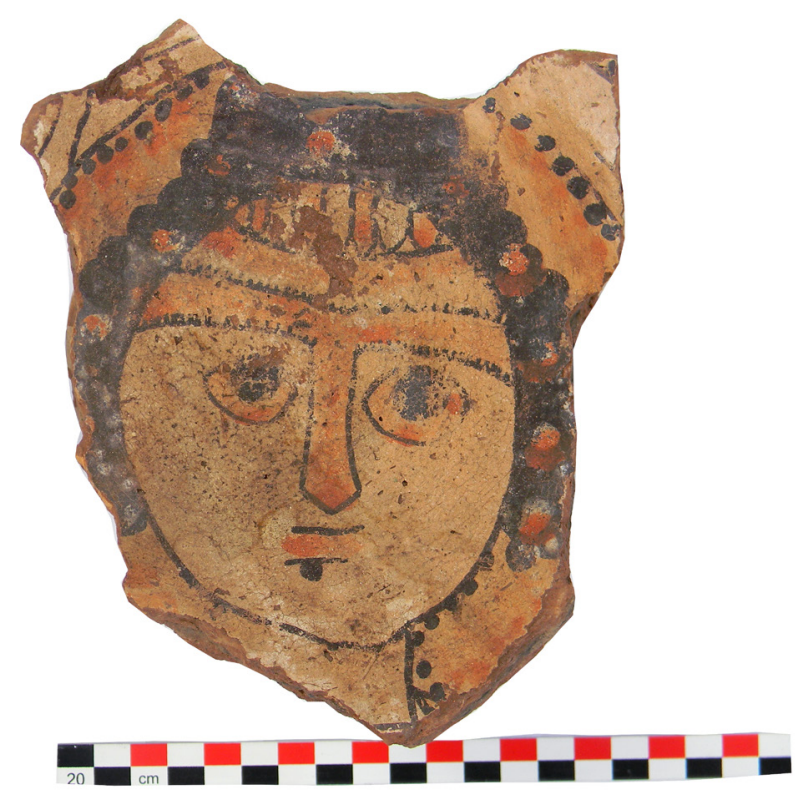

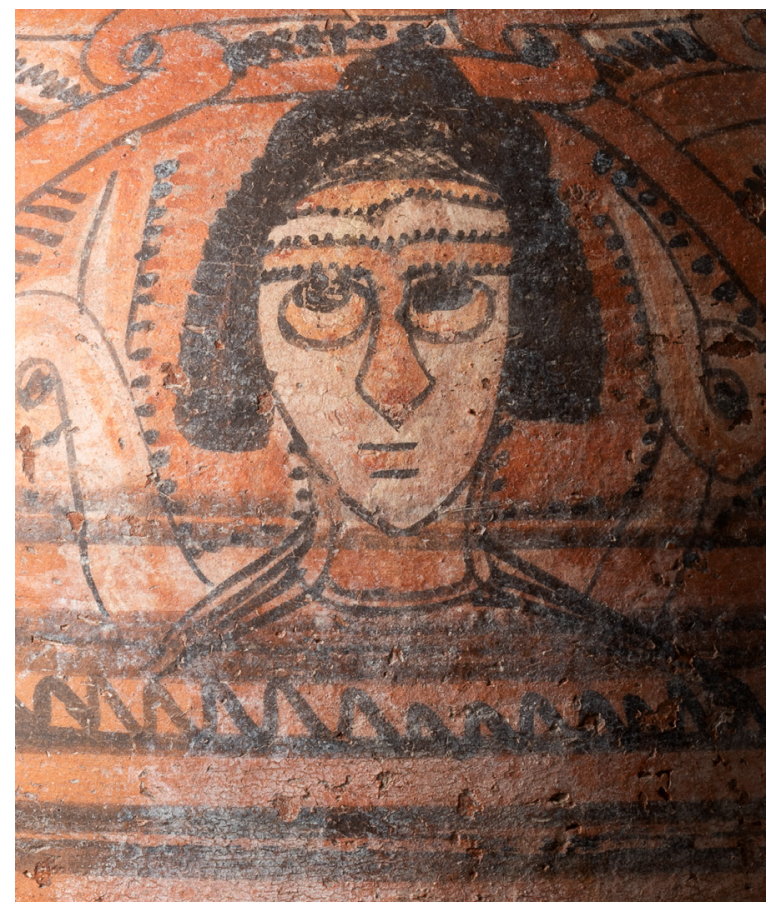

Fig. 10: Details of the depiction of the face on the Turin jar (left) and Manqabad cup (right). Photo by Nicola Dell'Aquila and Federico Taverni/Museo Egizio (left); photo by Ilaria Incordino (right). 


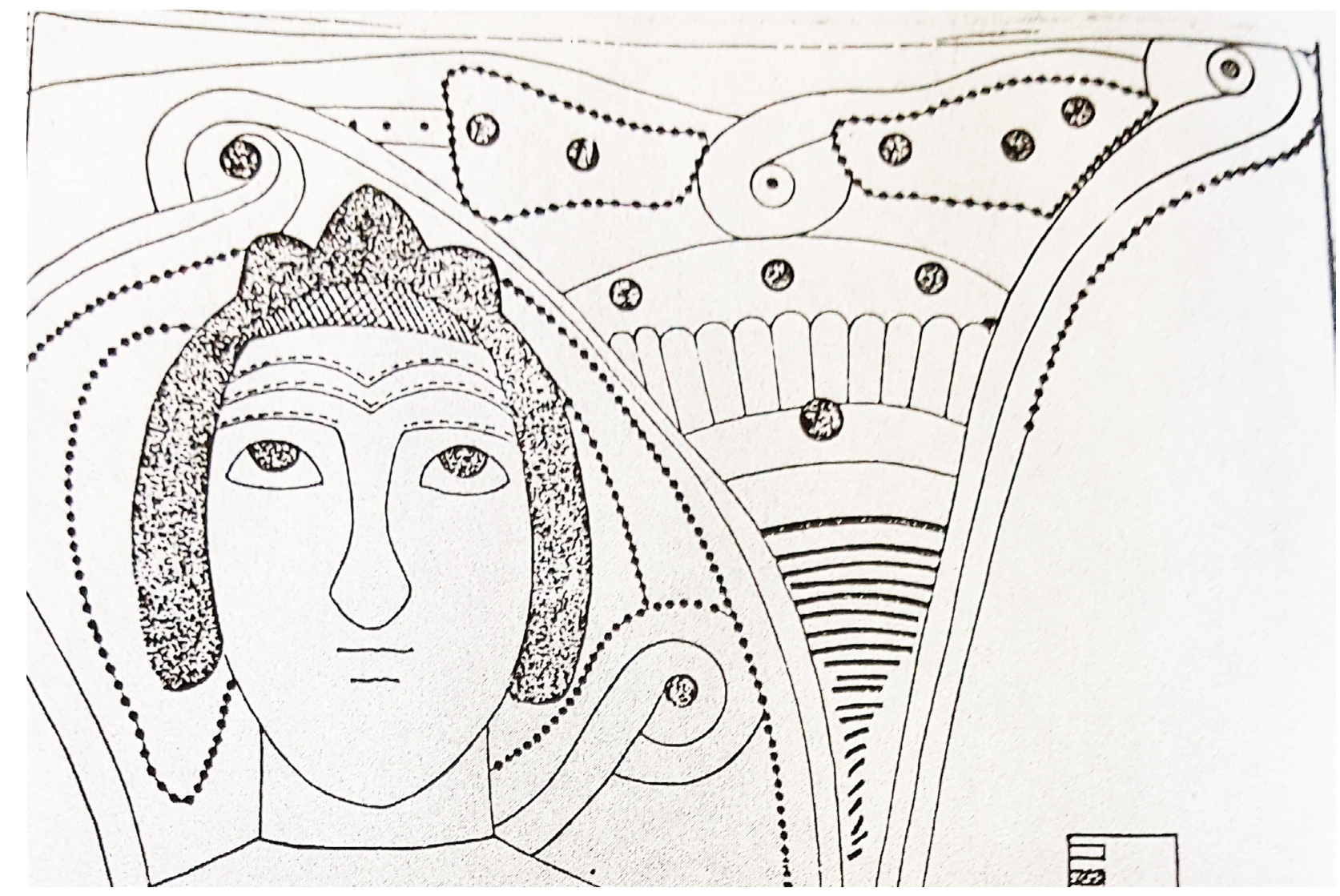

Fig. 11: Decoration of a Type E 'Saqqara jar' from the Coptic Museum of Cairo (inv. no. 10407). From Mohamed, in: Immerzeel and van der Vliet (eds.), Coptic Studies, p. 1254.

and a sort of diadem on the forehead, with vertical red and cream banded elements on the Manqabad cup and a black mesh pattern on the Turin jar. A similar mesh motif can be observed on the forehead of another female (?) image painted on a jar at the Coptic Museum in Cairo (inv. no. 10407; Fig. 11) dated to the sixth-seventh century $\mathrm{AD}$.

The rendering of the eyes (quite big, round and outlined in black) is very similar, even though the figure on the Turin jar has eyes not represented frontally, unlike that on the Manqabad cup. In both instances, the mouth is formed by a single horizontal red line between two black lines; in the Manqabad figure, a black dot is added underneath to give the effect of shading between mouth and chin. In both figures, the eyebrows are rendered as a continuous red line, with the hair indicated by rows of small black dots meeting the nose line at right angles.

Moreover, there are rows of black dots running down the neck and surrounding the head of both figures, which could be interpreted as grapevines, based on parallels found, for example, on a painted cup from the Louvre Museum (E11907) dated to the seventh-eighth century AD. ${ }^{18}$ This painted cup has other morphological and iconographical elements in common with the Manqabad cup, such as the braided frame still visible in the upper left corner of the latter. Despite a few different details (the more elongated shape of the nose and the rounded instead of oval shape of the face on the Manqabad cup), the two female (?) figures depicted on the Turin jar and on the Manqabad cup thus seem very close to one another from a stylistic point of view. Both could possibly evoke a Dionysiac mood and represent an auspicious personification.

Further parallels can also be found in details of human representations on frescos, the influence of wall paintings on the pottery decoration during the Christian era in Egypt being well known. ${ }^{19}$ Some interesting comparisons can be made, for example, with some painted figures above the Virgin from a decorated niche in Apa Jeremiah Saqqara (1725) in the north-west section of monastic cells related to the main church, dated by Quibell to the first half of the sixth century $\mathrm{AD}^{20}$ (Fig. 12). The female heads 


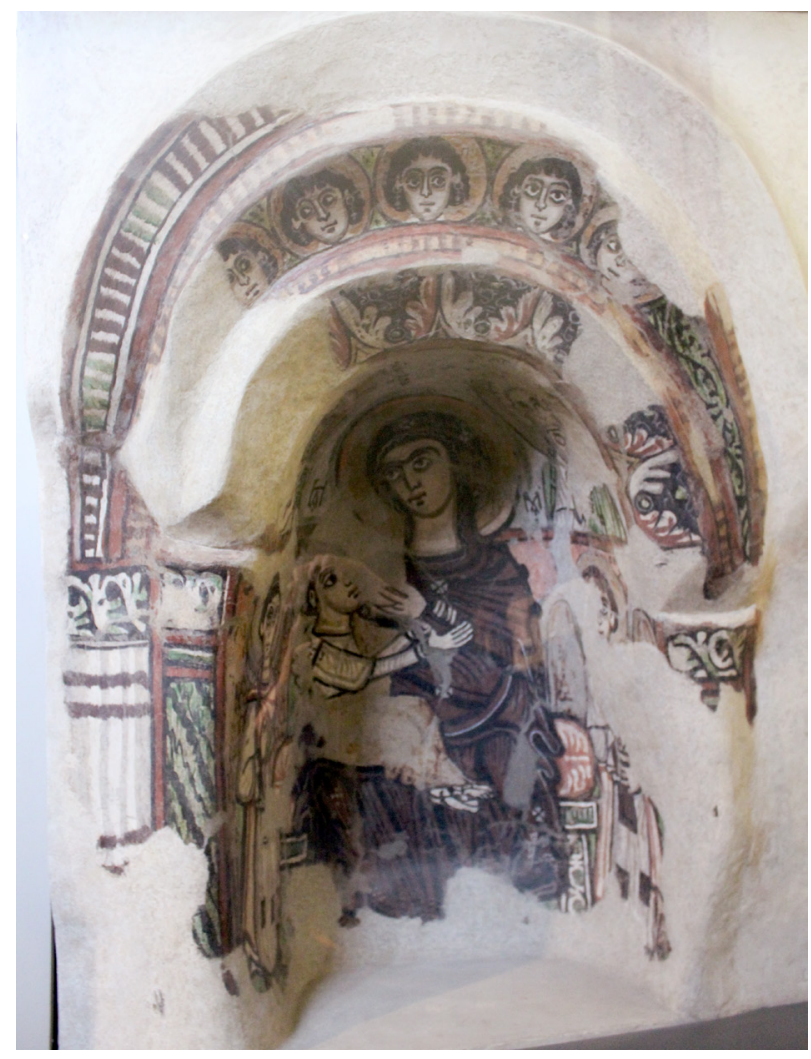

Fig. 12: Details of the Virgin with the Child from Apa Jeremiah (Coptic Museum Cairo, inv. 7987). Photo by llaria Incordino.

surrounding the Virgin have close points of resemblance with the Manqabad female head and the Turin jar figure, especially in the execution of the details of the face. Among these details, it is worth noticing the similar black line representing the figure's mouth, the curly headdress, the rich jewellery, the rounded-to-oval shape of the face and the continuous line connecting eyebrows and nose at an angle. The female heads at Apa Jeremiah have been interpreted as representations of virtues, a hypothesis that could also apply to the figures on the Manqabad cup and the Turin jar.

As Bolman argues, "the presence of a rich decorative repertoire in Egyptian monasteries can be explained only with a complex monastic visuality. There was a clear attempt by the monks to imitate and transform themselves into a host of superior beings and personifications through the wall decoration of these monasteries". ${ }^{21}$

The final goal was to be able to use images as tools for spiritual work in several ways. To quote Bolman again, "models of ascetic metamorphosis were angelic virtues, apostles, prophets and angels". ${ }^{22}$ It is quite plausible that such figures would also be depicted on pottery and other kind of supports.

\section{Conclusions}

The above stylistic and iconographic analysis of the Turin jar decoration suggests a date in the sixth or seventh century AD. This hypothesis is mainly based on parallels with similar decorated items. The several features shared with a painted jar from the Cairo Coptic Museum (inv. no. 9074) of Type C "Saqqara jars" can be considered as the most persuasive evidence in this regard.

This date is corroborated by a comparison with some painted figures above the Virgin in the decorated niche at Apa Jeremiah (no. 1725), in the northwest section of monastic cells connected to the main church. This decoration was dated by Quibell to the first half of the sixth century. As regards female representations, most of the parallel examples are also dated to the sixth-seventh century $\mathrm{AD}$, in particular the textile tabulae from Antinoopolis and the Type $\mathrm{E}$ "Saqqara jar" from the Coptic Museum of Cairo (inv. no. 10407).

As to the date of the Manqabad cup, a range between the sixth and eighth century AD also seems likely, based on parallels with similar pottery types from the same site. In the light of the above observations concerning the repertoire of female figures in wall paintings, it may be possible to narrow down the chronological range and suggest a date to the sixth century $\mathrm{AD}$ for this item, too. Indeed, the most striking parallel so far with the Manqabad lady are the female heads of personifications painted in the niche of chapel 1725 at Apa Jeremiah.

This conjectural date also relies on evidence deriving from the analysis of various archaeological materials found in the same sector of the site (2002). A typological study of the architectural elements, for instance, has clearly indicated a date between the second half of the fifth and the sixth century AD for all the different groups identified, and confirmed the existence of cultural and religious ties with the monastic centres of Saqqara and Bawit. ${ }^{23}$ As regards Manqabad decorated pottery in general, the main types found on the site can be dated to the sixth-seventh century $\mathrm{AD}$ and associated with the central and western section of the Northern Sector of the site. 


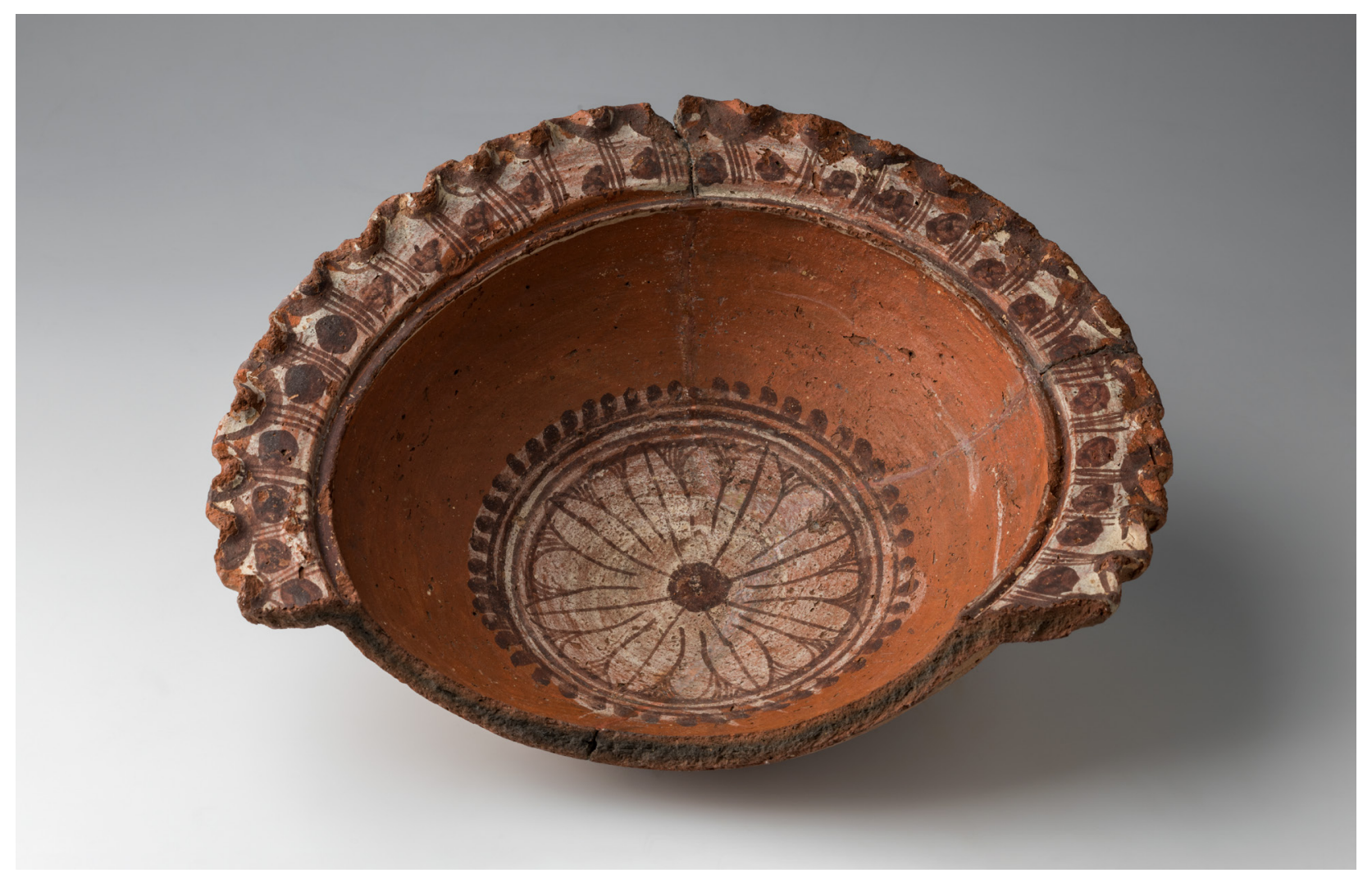

Fig. 13: Cup from el-Ashmunein, Turin Suppl. 2106. Photo by Nicola Dell'Aquila and Federico Taverni/Museo Egizio.

In the light of all the parallels pointed out in the present article, it therefore seems possible to suggest that the Turin ovoid jar with a female (?) representation could be included in the same chronological range as the Manqabad cup (sixth-seventh century AD).

In addition to this hypothetical dating, a similar provenance has to be stressed for both items analysed, namely, the Middle Egyptian region of Asyut. This could explain the correspondence both in style and decoration noted so far. Moreover, during a recent survey of some Byzantine vessels kept in the Museo Egizio in Turin, the present writer found further parallels with the Manqabad assemblage. For instance, there is a fragmentary painted cup from Schiaparelli's excavation at el-Ashmunein (Suppl. 2106; Fig. 13) that is quite similar in shape and size $(14.2 \times 28 \mathrm{~cm})$ to the Manqabad cup, although it has no anthropomorphic decoration but vegetal motifs. Another example is a fragmentary cup (Suppl. 2112; Fig. 14), also from el-Ashmunein, with a depiction of a female bust just below the rim on the inside $(8.3 \mathrm{x}$ $0.6 \mathrm{~cm})$.

Since the preliminary results of the study of the pottery assemblage from Manqabad have brought out the close links with the pottery production of the Middle Egypt region, in particular with the assemblages from Antinoopolis, Amarna (Kom el-Nana), possible that both Manqabad and Asyut were connected with the most important workshops in the

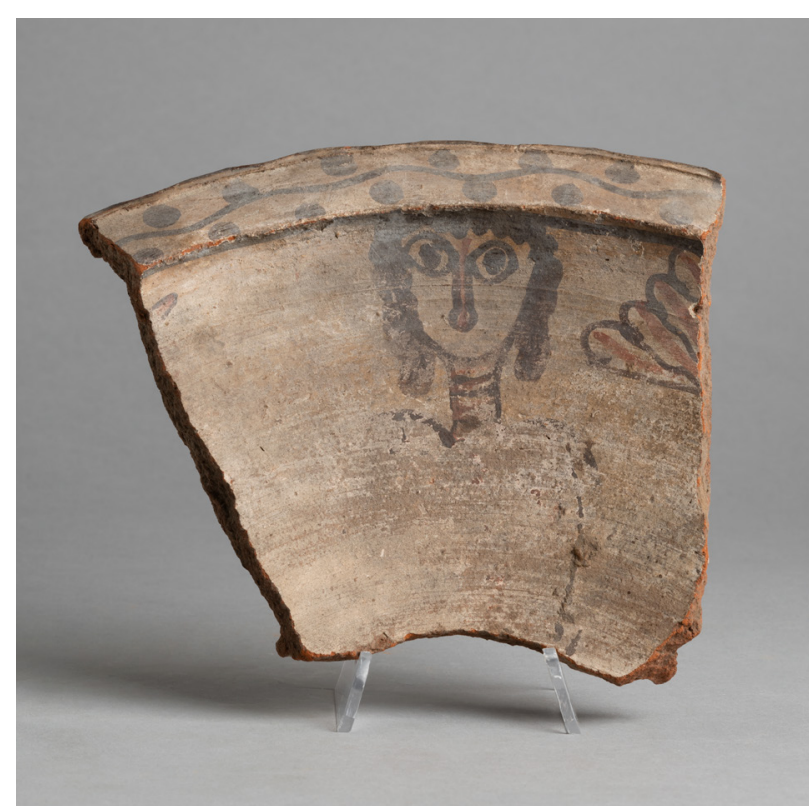

Fig. 14: Cup sherd from el-Ashmunein, Turin Suppl. 2112. Photo by Nicola Dell'Aquila and Federico Taverni/Museo Egizio. 
area (namely Antinoe and Amarna/Kom el-Nana). Ongoing fieldwork at Manqabad is currently focused on the search for evidence to support the hypothesis of a local production on the site (kilns). This will

\section{Notes}

${ }^{1}$ The present writer, a member of the Italian-Egyptian mission begun in 2012 at the monastery of "Abba Nefer the Hermit" at Manqabad, Asyut (Università degli Studi di Napoli “L’Orientale”, Università “La Sapienza” Rome, Supreme Council of Antiquities local Inspectorate and Restoration Sector), is currently in charge of the documentation and study of the pottery finds, which also include previously discovered ceramic items presently kept in the SCA storerooms of Shutby and el-Ashmunein. For a general overview of the Manqabad research project, see: Pirelli, C.I.S.A. Newsletter 4 (2014); Pirelli, C.I.S.A. Newsletter 5 (2015); Pirelli and Buzi, in Pirelli (ed.), Ricerche Italiane e Scavi in Egitto, 2013; Pirelli et al., in Buzi, Camplani and Contardi (eds.), Coptic Society, 2016; Pirelli et al., in Guidotti and Rosati (eds.), Proceedings of the XIth International Congress of Egyptologists held in Florence, 2017. For pottery-related methodological issues and the main types, see: Incordino, in Betrò et al. (eds.), Egitto e Vicino Oriente antichi, 2018.

${ }^{2}$ See Sbriglio, in Kahl et al., Asyut, 2019, pp. 86-93, and map on p. 76-77; see also Kahl, ibid., p. 37, and the list of "dispersed" finds, ibid., pp. 303-08. Information and references courtesy of Federico Poole. See also section 6 below.

${ }^{3}$ Török, After the Pharaohs, 2012, p. 226 ff.

${ }^{4}$ Swift, in Lavan et al. (eds.), Objects in Context, 2007, p. 400 . See some examples of decorated Roman coffins which duplicates the decoration of their original setting.

${ }^{5}$ Swift, in Lavan et al. (eds.), Objects in Context, 2007, p. 390.

${ }^{6}$ Swift, in Lavan et al. (eds.), Objects in Context, 2007, p. 388.

${ }^{7}$ Bolman, in McNally (ed.), Shaped Community, 2001, p. 45.

${ }^{8}$ See for example Louvre storage jar E 10993 and Petrie Museum pottery sherd UC 65403.

${ }^{9}$ Bourriau, Umm el-Ga'ab, 1981, p. 93. The sherd was found on the surface of the Coptic site in the Animal Necropolis at Saqqara, which seems not to have been used after the mid-sixth century $\mathrm{AD}$, according to the date range of imported pottery. Therefore, even if this type of large storage jar continued in use at least until the middle of the seventh century, it is not likely that the Saqqara specimens could have outlived the occupation phase of the settlement; they are therefore generally dated to the fifth-to-mid-sixth century AD.

${ }^{10}$ Bourriau, Umm el-Ga'ab, 1981, p. 93.

${ }^{11}$ Incordino, SAK 47, 2019. For the "Dyonisiac-portrait", see Duncan-Flowers et al., Art and Holy Powers, 1989, pp. 13-14. hopefully be confirmed by the future excavation of the large heap of pottery south of the enclosure wall, ${ }^{24}$ a location that could be considered suitable to host such structures.
${ }^{12}$ Xanthopoulou, Mouseio Benaki 10 (2010), p. 35, http:// dx.doi.org/10.12681/benaki.25.

${ }^{13}$ Xanthopoulou, Mouseio Benaki 10 (2010), p. 35, http:// dx.doi.org/10.12681/benaki.25.

${ }^{14}$ Kahl et al., Asyut, 2019, pp. 222 and 227. Information courtesy of Paolo Del Vesco.

${ }^{15}$ Incordino, SAK 47 (2019).

${ }^{16}$ Mohammed, in Immerzeel and van der Vliet (eds.), Coptic Studies on the Threshold of a New Millennium, 2004, pp. 1238-239, fig. 11.

${ }^{17}$ Jane Faires, personal comunication.

${ }^{18}$ Exposition Internationale d'Art Byzantin, 1931, no. 589.

${ }^{19}$ Török, After the Pharaohs, 2012, p. 221.

${ }^{20}$ Quibell, Excavations at Saqqara, 1912, p. V.

${ }^{21}$ Bolman, in Bagnall (ed.), Egypt in the Byzantine World 300-700, 2007, p. 420.

${ }^{22}$ Bolman, in Bagnall (ed.), Egypt in the Byzantine World 300-700, 2007, p. 423.

${ }^{23}$ Salsano, Aegyptus 1 (2005).

${ }^{24}$ Pirelli, C.I.S.A. Newsletter 9 (2019 in press).

\section{Bibliography}

Auth, Susan, "Significance of Egyptian, Classical and Christian Themes in Coptic Art", in: Mat Immerzeel and Jacques van der Vliet (eds.), Coptic Studies on the Threshold of a New Millennium, vol. 2. Proceedings of the Seventh International Congress of Coptic Studies, Leiden August 27 - September 2, 2000, pp. 1141-158, Leuven 2004.

Ballet, Pascale, Nathalie Bosson and Marguerite Rassart-Debergh, Kellia II. L'ermitage copte QR 195.2: la céramique, les inscriptions, les décors (FIFAO 49), Le Caire 2003.

Ballet, Pascale and Anna Poludnikiewicz, Tebtynis V. La céramique des époques hellénistique et impériale. Campagnes 1988-1993. Production, consommation et réception dans le Fayoum méridional (FIFAO 68), Le Caire 2012.

Bailey, Donald M., Excavations at el-Ashmunein V. Pottery, Lamps and Glass of the Late Roman and Early Arab Periods. British Museum Expedition to Middle Egypt, London 1998.

Bolman, Elisabeth, "Depicting the Kingdom of Heaven: Paintings and Monastic Practice in Early Byzantine Egypt”, in: Roger S. Bagnall (ed.), Egypt in the Byzantine World 300-700, Cambridge 2007, pp. 408-33.

Bolman, Elisabeth, "Joining the Community of Saints: Monastic Paintings and Ascetic Practice in Early Christian Egypt", in: Sheila McNally (ed.), Shaping Community: The Art and Archaeology of Monasticism. Papers from a Symposium Held at the Frederick R. Weisman Museum University of Minnesota, March 10.12, 2000 (BAR-IS 941), Oxford 2001, pp. 41-56. 
Bolman, Elisabeth (ed.), The Red Monastery Church: Beauty and Asceticism in Upper Egypt, Yale 2016.

Bourriau, Janine, Umm el-Ga'ab. Pottery from the Nile Valley Before the Arab Conquest, Cambridge 1981.

Clédat, Jean, Le monastère et la nécropole de Baouit (MIFAO 111), Le Caire 1999.

Duncan-Flowers, Marjorie J., Eunice Dautermann Maguire and Henry P. Maguire, Art and Holy Powers in the Early Christian House, Chicago 1989.

Egloff, Michel, Kellia: la poterie copte. Quatre siècles d'artisanat et d'échanges en Basse-Égypte (RSAC 3), Genève 1977.

Exposition internationale d'art byzantin : 28 mai - 9 juillet 1931 : Musée des arts décoratifs, Palais du Louvre, Pavillon de Marsan, n.p. 1931.

Faiers, Jane, Late Roman Glassware and Pottery from Amarna and Related Studies (EES ExcMem 102), London 2013.

Faiers, Jane (ed.), Late Roman Pottery at Amarna and Related Studies (EES ExcMem 72), London 2005.

Faiers, Jane, "Wadi Sarga Revisited: A Preliminary Study of the Pottery Excavated in 1913/14", in: Elisabeth R. O'Connell (ed.), Egypt in the First Millennium AD: Perspectives from New Fieldwork (British Museum Publications on Egypt and Sudan 2), Leuven 2014, pp. 177-89.

Górecki, Tomasz, “Coptic Painted Amphorae from Tell Atrib - Introductory Remarks on Decoration”, in: Wlodzimierz Godlewski (ed.), Coptic and Nubian Pottery. Part I. International Workshop, Nieborow, August, 28-31, 1988 (Occasional Paper National Museum in Warsaw), Warsaw 1990, pp. 34-48.

Incordino, Ilaria, "Analysis of a Painted Female Head Among the Pottery Decoration from the Monastery of Abba Nefer at Manqabad (Asyut)", SAK 47, 2019, pp. 107-16.

Incordino, Ilaria, “Criticità e prospettive nello studio del materiale ceramico proveniente dal monastero di « Abba Nefer l'eremita » a Manqabad (Asyut)" in: Marilina Betrò, Stefano de Martino, Gianluca Miniaci, and Frances Pinnock (eds.), Egitto e Vicino Oriente antichi: tra passato e futuro. Studi e ricerche sull'Egitto e il Vicino Oriente in Italia. I convegno nazionale, Pisa, 5-6 giugno 2017, Pisa 2018, pp. 171-77.

Kahl, Jochem, Alice Maria Sbriglio, Paolo Del Vesco, and Marcella Trapani, Asyut: The Excavations of the Italian Archaeological Mission (1906-1913) (Studi del Museo Egizio 1), Modena 2019.

Maguire, Eunice Dauterman, Henry P. Maguire, and Maggie J. Duncan-Flowers, Art and Holy Powers in the Early Christian House (Illinois Byzantine Studies 2), Urbana and Chicago 1989.

Mohamed, Fatma Mahmoud, "Quelques jarres à décor peint, provenant du monastere de Saint-Jérémie à Saqqara”, in: Mat Immerzeel and Jacques van der Vliet (eds.), Coptic Studies on the Threshold of a New Millennium, vol. 2. Proceedings of the Seventh International Congress of Coptic Studies, Leiden, August 27 - September 2, 2000, Leuven 2004, pp. 1231-257.

Pintaudi, Rosario (ed.), Antinoupolis I. Scavi e Materiali, Firenze 2008.

Pirelli, Rosanna and Paola Buzi, "Il progetto italo-egi- ziano di studio e conservazione del " monastero di Abba Nefer » a Manqabad (Asyut)", in: Rosanna Pirelli (ed.), Ricerche Italiane e Scavi in Egitto, VI, Cairo 2013, p. 197-209.

Pirelli, Rosanna, “The Italian-Egyptian Project of Study and Conservation of the Monastery of Abba Nefer, Manqabad (Asyut): First and Second Campaign”, C.I.S.A. Newsletter 5 (2014), pp. 441-54.

Pirelli, Rosanna, “The Italian-Egyptian Project of Study and Conservation of the Monastery of Abba Nefer, Manqabad (Asyut): Third Campaign", C.I.S.A. Newsletter 6 (2015), pp. 255-65.

Pirelli, Rosanna, Angela Bosco, Paola Buzi, Andrea D’Andrea, Mohammed Kenawi, Ilaria Incordino, Pasquale Musella, Stefania Mainieri, M. Diletta Pubblico, Adìndrea Ragionieri, and Anna Salsano, “The Italian Egyptian Project of Study and Conservation of the Monastery of Abba Nefer at Manqabad 2018: Fifth Campaign”, C.I.S.A. Newsletter 9 (2018), pp. 305-50.

Pirelli, Rosanna, Paola Buzi, Roberta Giunta, Ezzat Salib, and Vanda Mastromanno, "The Coptic Site of Manqabad: An Italian-Egyptian Project”, in: Paola Buzi, Alberto Camplani and Federico Contardi (eds.), Coptic Society, Literature and Religion from Late Antiquity to Modern Times Proceedings of the Tenth International Congress of Coptic Studies, Rome, September 17th22nd, 2012 and Plenary Reports of the Ninth International Congress of Coptic Studies, Cairo, September 15th19th, 2008, II, (OLA 247), Leuven 2016, pp. 1433-446.

Pirelli, Rosanna, Paola Buzi, Ilaria Incordino, and Anna Salsano, “The Results of the First Four Seasons' Work of the Italian Egyptian Mission at the Monastery of Abba Nefer at Manqabad", in: Maria Cristina Guidotti and Gloria Rosati (eds.), Proceedings of the XIth International Congress of Egyptologists held in Florence, 2330 August 2015 (Archaeopress Egyptology 19), Oxford 2017, pp. 491-98.

Quibell, James Edwards, Excavations at Saqqara (19081909, 1909-1910). The Monastery of Apa Jeremias, Cairo, 1912.

Rowland, Ingrid and Howe Thomas (eds.), Vitruvius. Ten Books on Architecture, Cambridge 1999.

Salsano, Anna, "Stone Architectural Elements of Manqabad. Season 2014”, Aegyptus 95 (2015), pp. 91-111.

Schrunk, Ivančica, "Spiritual Economy and Spiritual Craft: Monastic Pottery Production and Trade”, in: Philip Harl Sellew, Columba Stewart, Elisabeth Bolman and Andersen Elmer (eds.), Living for Eternity: The White Monastery and its Neighborhood. Proceedings of a Symposium at the University of Minnesota, Minneapolis March 6-9, 2003, Minneapolis, 2009, pp. 83-96.

Spencer, Jeffrey, Donald Bailey, and Vivian Davies, British Museum Expedition to Middle Egypt: Ashmunein (1980) (BMOP 37), London 1982.

Swift, Ellen, "Decorated Vessels: The Function of Decoration in Late Antiquity”, in: Luke Lavan, Ellen Swift and Toon Putzey (eds.), Objects in Context, Objects in Use: Material Spatiality in Late Antiquity (Late Antique Archaeology 5) Leiden and Boston 2007, pp. 385-409.

Török, Lásló (ed.), After the Pharaohs: Treasures of Coptic Art from Egyptian Collections (Catalogue of the Exhibition, Budapest, Museum of Fine Arts Budapest 18 
March-18 May 2005), Budapest 2012.

Török, Lásló, Transfigurations of Hellenism. Aspects of Late Antique Art in Egypt AD 250-700 (ProblÄg 23), Leiden 2005.
Xanthopoulou, Maria, "Martyrs, Monks, and Musicians: Two Enigmatic Coptic Vases in the Benaki Museum and Their Parallels" Mouseio Benaki 10 (2010), pp. 19-51. http://dx.doi.org/10.12681/benaki.25. 